Introduction: Gastric cancer, one of the most common cancers in the world, rarely metastasizes to the ovaries. Ovarian metastases of gastric signet ring cell cancer (SRCC) are referred to as Krukenberg tumors and account for $1-2 \%$ of all ovarian cancers. Here, we analyze the characteristics, treatment, and prognosis of patients with Krukenberg tumors.

Material and methods: We retrospectively analyzed the demographic characteristics, treatment modalities, progression-free survival (PFS), and overall survival (OS) of patients who were diagnosed with Krukenberg tumors of gastric cancer origin and who underwent treatment and follow-up between January 2005 and January 2012 in the Ankara Oncology Education and Research Hospital.

Results: Among 1755 patients diagnosed with gastric cancer between January 2005 and January 2012, eight patients $(0.45 \%)$ with histopathologically identified Krukenberg tumors were enrolled. The median age of the eight patients was 42.2 years (range, 32-69 years). Two (25\%) of the patients were stage $3 \mathrm{~A}$, two (25\%) were stage $3 C$, and four (50\%) were stage 4 at the time of diagnosis. The median PFS was 13.2 months (1-25 months), the median OS after the original diagnosis was 16.7 months (1-41 months), and the median OS after ovarian metastasis was 3.6 months (1-10 months).

Discussion: Krukenberg tumors were seen particularly in young patients and more frequently during the premenopausal period. The prognosis was poor. When only the ovaries were affected, metastasectomy prolonged the survival time.

Key words: gastric cancer, ovary, Krukenberg tumor, metastasectomy.

Contemp Oncol (Pozn) 2013; 17 (6): 515-519 DOI: $10.5114 /$ wo.2013.37542

\section{Isolated ovarian metastasis of gastric cancer: Krukenberg tumor}

\author{
Ummugul Uyeturk ${ }^{1}$, Serife Hulya Arslan², Oznur Bal², Ulku Yalcintas Arslan², \\ Omur Berna Cakmak Oksuzoglu²
}

${ }^{1}$ Department of Medical Oncology, Faculty of Medicine, Abant Izzet Baysal University, Bolu, Turkey

${ }^{2}$ Clinics of Medical Oncology, Ankara Oncology Education and Research Hospital, Ankara, Turkey

\section{Introduction}

Although the frequency of gastric cancer varies by region, it is the fourth most common cancer in the world and the second most common cancer leading to death $[1,2]$. Gastric cancer metastasizes via hematogenous and lymphogenous routes, peritoneal seeding and direct invasion. The liver, peritoneal surfaces and regional or distant lymph nodes are the most common metastatic sites. Metastasis occurs less frequently in the central nervous system, bones, lungs, soft tissues, and ovaries [3]. Metastases of mucin-secreting signet ring cell cancer (SRCC) to ovarian tissues are referred to as Krukenberg tumors, which may also originate from cancers of the colon, appendix, and breasts [4]. These tumors are rare, accounting for $1-2 \%$ of all ovarian cancers $[4,5]$.

Here, we analyzed the characteristics, treatment modalities, and prognosis, including progression-free survival (PFS) and overall survival (OS), of patients with Krukenberg tumors that originated from gastric cancer.

\section{Material and methods}

The medical records of patients who were diagnosed with gastric cancer and who underwent follow-up and treatment in the Ankara Oncology Education and Research Hospital between January 2005 and January 2012 were evaluated retrospectively, and patients with histopathologically identified ovarian metastasis were enrolled in the study. All cancers other than ovarian metastases of gastric origin were excluded from the study. For each enrolled patient, the age, Eastern Cooperative Oncology Group (ECOG) performance status, menopausal status, complaints, date of histopathological diagnosis of the primary tumor, treatment modalities after diagnosis (surgery, radiotherapy, and chemotherapy), date of histopathological diagnosis of ovarian metastasis, diagnostic methods, and final follow-up date were recorded. The median OS and PFS were calculated.

The data were analyzed using SPSS for Windows, version 11.5 .

\section{Results}

Among 1755 patients diagnosed with gastric cancer between January 2005 and January 2012 at the Ankara Oncology Education and Research Hospital, eight patients (0.45\%) with histopathologically identified Krukenberg tumors were enrolled. Radiological findings of a patient are presented in Fig. 1 and Fig. 2. Their median age was 42.2 years (range, 32-69 years); seven (87.5\%) were premenopausal, and one (12.5\%) was post-menopausal. The performance status was ECOG 1 in seven (87.5\%) patients and ECOG 2 in one patient (12.5\%). Upon admission, four (50\%) of the patients had abdominal pain, three (37.5\%) had abdominal swelling, and one (12.5\%) had complaints of nausea and vomiting. One patient (12.5\%) had adenocarcinoma and 
SRCC, two (25\%) had adenocarcinoma, and five (62.5\%) had SRCC based on histopathological examinations of the specimens of gasters. Four (50\%) of the patients underwent surgery (distal subtotal gastrectomy in two; total gastrectomy in two). The primary tumors in the other four patients were considered to be inoperable. At the time of diagnosis, two patients $(25 \%)$ were stage $3 \mathrm{~A}$, two $(25 \%)$ were stage 3C, and four (50\%) were stage 4. Ovarian metastasis was diagnosed by ovarian biopsy in three patients (37.5\%), by unilateral salpingo-oophorectomy in three patients (37.5\%), and by bilateral salpingo-oophorectomy in two patients (25\%). Histopathological examinations of ovaries in all patients were reported as SRCC. The four patients with a stage 3 diagnosis were treated with the protocol described by Macdonald et al. [6]. This protocol is defined as: 5 -fluorouracil (FU) $425 \mathrm{mg} / \mathrm{m}^{2} /$ day (days 1 to 5) plus folinic acid $20 \mathrm{mg} / \mathrm{m}^{2} /$ day (days 1 to 5), one month later 5 -FU 400 $\mathrm{mg} / \mathrm{m}^{2} /$ day (days 1 to 4) plus folinic acid $20 \mathrm{mg} / \mathrm{m}^{2} /$ day (days 1 to 4 ) and the last 3 days of radiotherapy (RT), 1.8 Gy/day to $45 \mathrm{~Gy}$, one month after completion of RT, 5-FU $425 \mathrm{mg} / \mathrm{m}^{2} /$ day (days 1 to 5) and folinic acid $20 \mathrm{mg} / \mathrm{m}^{2}$ / day every 4 weeks $\times 2$ cycles (FUFA). Chemotherapy was administered as palliative first-line treatment in the four patients with metastasis detected after adjuvant therapy and in two of the four patients with metastasis at the time of the original diagnosis. In chemotherapy, the protocol of Van Cutsem et al. was used, which is defined as docetaxel $75 \mathrm{mg} / \mathrm{m}^{2} /$ day and cisplatin $75 \mathrm{mg} / \mathrm{m}^{2} /$ day plus 5 -FU 750 $\mathrm{mg} / \mathrm{m}^{2} /$ day (days 1 to 5 ) every 3 weeks (DCF) [7].

In one patient who was diagnosed with SRCC after a right oophorectomy, the primary tumor could not be found at the time of the evaluation, which included gastroscopy; she was thought to have primary ovarian SRCC and received carboplatin/paclitaxel chemotherapy. When she was evaluated for tumor response after three cycles of chemotherapy, computed tomography of the abdomen revealed thickening of the wall of the stomach, and she was diagnosed with gastric cancer after a second gastroscopy. The remaining patient was unable to undergo chemotherapy due to acute renal failure.

The median PFS was 13.2 months (range, 1-25 months), the median OS after the original diagnosis was 16.7

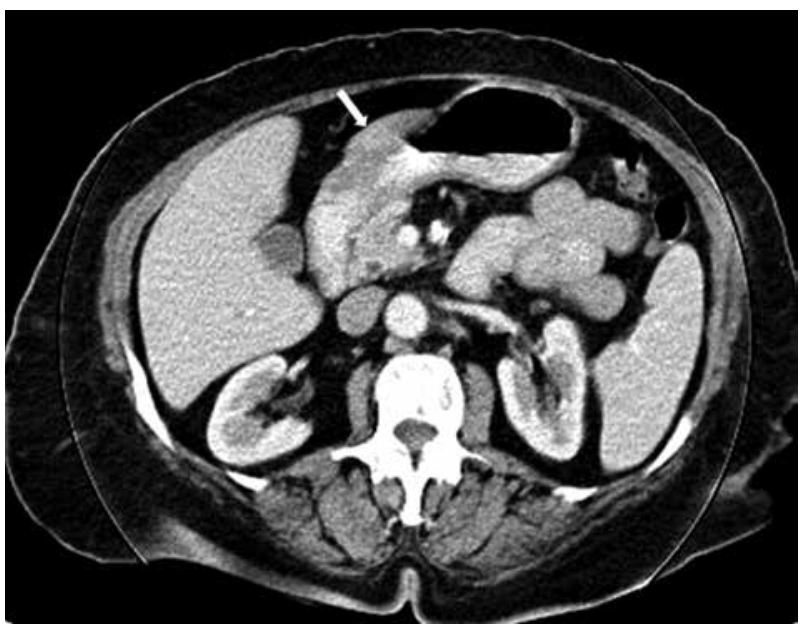

Fig. 1. Computed tomography of primary gastric cancer months (range, 1-41 months), and the median OS after ovarian metastasis was 3.6 months (range, 1-10 months). The survival time was longest for the patients who were stage $3 \mathrm{~A}$ at the time of diagnosis and underwent bilateral salpingo-oophorectomy after developing ovarian metastasis (Table 1).

\section{Discussion}

Gastric cancer occurs mainly in people between the ages of 50 and 70 [8]. Gastric SRCC is less common than adenocarcinoma, with previous studies reporting incidences between $3.4 \%$ and $15.1 \%$ [9-13]. Deep invasion, lymph node involvement, and peritoneal metastasis are more frequent in gastric SRCC compared with other subtypes of gastric cancer, and its prognosis is worse [14]. Gastric SRCC is more infiltrative, with greater affinity for lymphatic tissue and a higher rate of peritoneal carcinomatosis, compared with the reported prognosis of gastric adenocarcinoma. Therefore, extended lymph node dissection and curative surgery are recommended for this histological type $[10,11,13]$.

Ovarian metastasis of gastric cancer was first observed by Friedrich Ernst Krukenberg in 1896. Previously, all metastatic ovarian cancers had been referred to as Krukenberg tumors; however, Novak and Gray created new diagnostic criteria to eliminate any confusion. Accordingly, a mucin-secreting SRCC tumor in the dense fibroblastic stroma of the ovary is referred to as a Krukenberg tumor [15]. Primary SRCC of the ovaries and Krukenberg tumors may morphologically resemble one another, making the differential diagnosis difficult. Immunohistochemical evaluation can be beneficial in differentiating between primary ovarian cancers and metastatic ovarian cancers. Cytokeratin (CK)7 negative/CK20 positive or CK7 positive/CK20 positive immunophenotype (CK20 positivity, in particular) is used in the diagnosis of metastatic gastrointestinal cancer. Furthermore, positive staining for the gastric mucin gene MUC5AC is important in the diagnosis of metastatic gastric cancer over primary ovarian adenocarcinoma [16]. Nevertheless, it is important to clinically distinguish these tumors because of the significant differences in their treatment protocols, chemotherapy response,

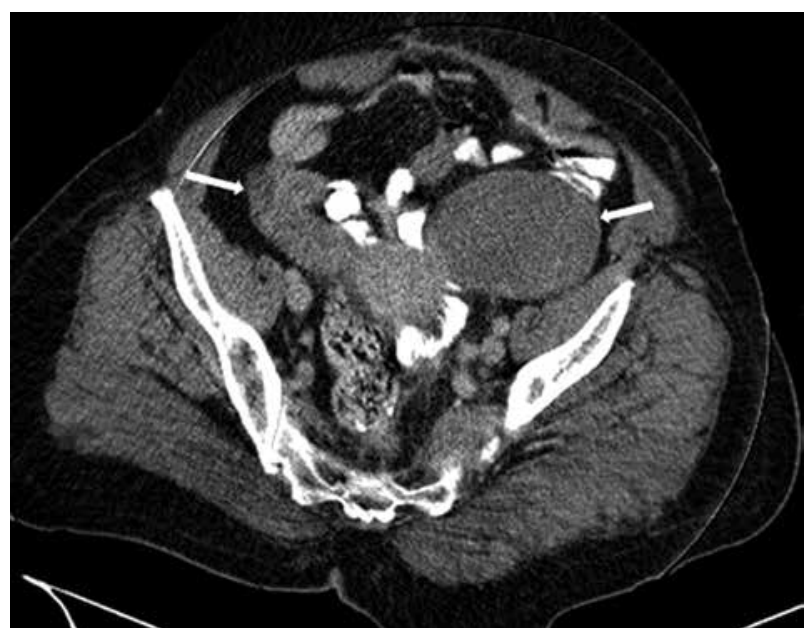

Fig. 2. Computed tomography of Krukenberg tumor 
Table 1. General features of Krukenberg tumor originating in the gaster of patients

\begin{tabular}{|c|c|c|c|c|c|c|c|c|}
\hline & Case 1 & Case 2 & Case 3 & Case 4 & Case 5 & Case 6 & Case 7 & Case 8 \\
\hline Age & 37 & 51 & 36 & 42 & 32 & 69 & 39 & 32 \\
\hline $\begin{array}{l}\text { Menopausal } \\
\text { status }\end{array}$ & $\begin{array}{c}\text { premeno- } \\
\text { pausal }\end{array}$ & $\begin{array}{c}\text { premeno- } \\
\text { pausal }\end{array}$ & $\begin{array}{c}\text { premeno- } \\
\text { pausal }\end{array}$ & $\begin{array}{c}\text { premeno- } \\
\text { pausal }\end{array}$ & $\begin{array}{c}\text { premeno- } \\
\text { pausal }\end{array}$ & $\begin{array}{c}\text { postmeno- } \\
\text { pausal }\end{array}$ & $\begin{array}{c}\text { premeno- } \\
\text { pausal }\end{array}$ & $\begin{array}{c}\text { premeno- } \\
\text { pausal }\end{array}$ \\
\hline ECOG & 1 & 1 & 1 & 1 & 2 & 1 & 1 & 1 \\
\hline $\begin{array}{l}\text { Initial } \\
\text { complaint }\end{array}$ & $\begin{array}{c}\text { stomacha- } \\
\text { che }\end{array}$ & $\begin{array}{c}\text { stomacha- } \\
\text { che }\end{array}$ & $\begin{array}{c}\text { stomacha- } \\
\text { che }\end{array}$ & $\begin{array}{l}\text { abdominal } \\
\text { swelling }\end{array}$ & $\begin{array}{c}\text { abdominal } \\
\text { swelling }\end{array}$ & $\begin{array}{c}\text { stomacha- } \\
\text { che }\end{array}$ & $\begin{array}{l}\text { abdominal } \\
\text { swelling }\end{array}$ & $\begin{array}{l}\text { nausea, } \\
\text { vomiting }\end{array}$ \\
\hline $\begin{array}{l}\text { Pathology of } \\
\text { gaster }\end{array}$ & SRCC & SRCC & $\begin{array}{c}\text { SRCC + } \\
\text { adenocarci- } \\
\text { noma }\end{array}$ & SRCC & SRCC & $\begin{array}{c}\text { adenocarci- } \\
\text { noma }\end{array}$ & SRCC & $\begin{array}{c}\text { adenocarci- } \\
\text { noma }\end{array}$ \\
\hline $\begin{array}{l}\text { Gastric } \\
\text { operation }\end{array}$ & DSG & $\begin{array}{c}\text { TG+D2 } \\
\text { lymph node } \\
\text { dissection }\end{array}$ & $\begin{array}{l}\text { TG+ D2 } \\
\text { lymph } \\
\text { node dis- } \\
\text { section }\end{array}$ & no & no & no & no & DSG \\
\hline Stage & $\begin{array}{c}3 C \\
\text { (20/33 } \\
\text { lymph } \\
\text { node) }\end{array}$ & $\begin{array}{c}3 C \\
(13 / 18 \\
\text { lymph } \\
\text { node) }\end{array}$ & $\begin{array}{c}3 A \\
(23 / 35 \\
\text { lymph } \\
\text { node })\end{array}$ & 4 & 4 & 4 & 4 & $\begin{array}{c}3 \mathrm{~A} \\
(13 / 18 \\
\text { lymph } \\
\text { node) }\end{array}$ \\
\hline $\begin{array}{l}\text { Diagnosis of } \\
\text { metastasis }\end{array}$ & $\begin{array}{l}\text { ovarian } \\
\text { biopsy }\end{array}$ & $\begin{array}{l}\text { ovarian } \\
\text { biopsy }\end{array}$ & $\begin{array}{l}\text { bilateral } \\
\text { salpingo- } \\
\text {-oophorec- } \\
\text { tomy }\end{array}$ & $\begin{array}{l}\text { right salpin- } \\
\text { go-oopho- } \\
\text { rectomy }\end{array}$ & $\begin{array}{l}\text { ovarian } \\
\text { biopsy }\end{array}$ & $\begin{array}{l}\text { right salpin- } \\
\text { go-oopho- } \\
\text { rectomy }\end{array}$ & $\begin{array}{l}\text { right salpin- } \\
\text { go-oopho- } \\
\text { rectomy }\end{array}$ & $\begin{array}{c}\text { bilateral } \\
\text { salpingo- } \\
\text {-oophorec- } \\
\text { tomy }\end{array}$ \\
\hline $\begin{array}{l}\text { Pathology of } \\
\text { ovary }\end{array}$ & SRCC & SRCC & SRCC & SRCC & SRCC & SRCC & SRCC & SRCC \\
\hline $\begin{array}{l}\text { Adjuvant } \\
\text { chemotherapy }\end{array}$ & FUFA & FUFA & FUFA & no & no & no & no & FUFA \\
\hline Radiotherapy & yes & yes & yes & no & no & no & no & yes \\
\hline $\begin{array}{l}\text { PFS } \\
\text { (month) }\end{array}$ & 19 & 15 & 25 & 4 & 1 & 7 & 4 & 31 \\
\hline $\begin{array}{l}\text { First line } \\
\text { palliative } \\
\text { chemotherapy }\end{array}$ & DCF & DCF & DCF & $\begin{array}{c}\text { carbopla- } \\
\text { tin+ paclita- } \\
\text { xel }\end{array}$ & no & DCF & DCF & DCF \\
\hline $\begin{array}{l}\text { Time to } \\
\text { metastasis } \\
\text { or death } \\
\text { (months) }\end{array}$ & 7 & 3 & 4 & 2 & 1 & 1 & 1 & 10 \\
\hline $\begin{array}{l}\text { OS } \\
\text { (months) }\end{array}$ & 26 & 18 & 29 & 6 & 1 & 8 & 5 & 41 \\
\hline Last status & exitus & exitus & exitus & exitus & exitus & exitus & exitus & exitus \\
\hline
\end{tabular}

ECOG - Eastern Cooperative Oncology Group, SRCC - signet ring cell carcinoma, PFS - progression-free survival, OS - overall survival, DSG - distal subtotal gastrectomy, TG - total gastrectomy, FUFA - 5-fluorouracil, folinic acid, DCF-docetaxel, cisplatin, 5-fluorouracil

and prognosis [17]. There are some cases in the literature in which an initially diagnosed metastatic carcinoma of the ovary was subsequently, upon further investigation, understood to have been early gastric cancer. In cases with an early-stage primary tumor, lymphatic invasion may be the most likely way of metastasis. In the present series, one case that had been accepted and treated as a primary ovarian tumor when a mass was detected in the ovarian tissue was found not to be a primary ovarian tumor after further investigation. Instead, after three cycles of chemotherapy, the primary tumor was identified as gastric cancer [18-20].

A Krukenberg tumor can vary in terms of its depth and the number of metastatic lymph nodes derived from the primary tumor, and these factors influence survival $[21,22]$.

Surgery is the main treatment in the absence of metastases for medically fit patients. However, considering local and distant recurrence of gastric cancer, chemotherapy and radiation therapy are also included [23]. Postoperative chemoradiotherapy is shown to decrease local recurrence in patients with locally advanced gastric cancer. Progression-free survival and OS data demonstrate a continued strong benefit from postoperative chemoradiotherapy $[6,24,25]$. Palliative options including radiotherapy may be applied for unresectable, or metastatic gastric cancer $[23,26]$. 
Metastatic or inoperable gastric cancer patients have a poor prognosis with a median OS, if untreated, of 3 to 5 months. Chemotherapy combined with the best supportive care can improve the survival of these patients. Compared with single-agent chemotherapy, combination chemotherapy was reported to be superior in terms of symptom control and response rate [27]. The DCF chemotherapy protocol significantly improved PFS, OS, and response rate in gastric cancer patients [7]. Despite the development of chemotherapeutic agents for treating metastatic disease, the prognosis is usually poor, with a 5 -year survival rate of $5-15 \%$ [28].

Chemotherapy is currently the standard treatment for advanced gastric cancer, but the efficacy of metastasectomy is under investigation. In a study of metastasectomy for liver metastasis, which is one of the most common organ metastases of gastric cancer, survival was prolonged when there was no peritoneal dissemination and there were fewer than two liver metastases [29]. Another study showed that serosal invasion and liver tumor size greater than $5 \mathrm{~cm}$ were indicators of a poor prognosis [30].

Several studies have evaluated the effectiveness of metastasectomy for ovarian metastasis of gastric cancer. In patients with Krukenberg tumors originating from the stomach, overall survival times were 14.1 and 8 months for patients who did and did not undergo metastasectomy, respectively, indicating that metastasectomy improves survival [31]. In another study, patients with primary gastric tumors resulting in Krukenberg tumors and who underwent metastasectomy had a survival time of 18.8 months, and the 3 -year survival rate was $15.8 \%$; the most important factors affecting survival were early diagnosis and resection of the tumor [32].

Ovarian metastasis of gastric cancer is not common. However, gastric SRCC occurs most frequently in young women during the premenopausal period. When the only metastatic site is the ovary, metastasectomy can prolong survival time.

The authors declare no conflict of interests.

\section{References}

1. Jemal A, Center MM, DeSantis C, Ward EM. Global patterns of cancer incidence and mortality rates and trends. Cancer Epidemiol Biomarkers Prev 2010; 19: 1893-907.

2. Ferlay J, Shin HR, Bray F, Forman D, Mathers C, Parkin DM. Estimates of worldwide burden of cancer in 2008: GLOBOCAN 2008. Int J Cancer 2010; 127: 2893-17.

3. Ahn JB, Ha TK, Kwon SJ. Bone metastasis in gastric cancer patients. J Gastric Cancer 2011; 11: 38-45.

4. Kiyokawa T, Young RH, Scully RE. Krukenberg tumors of the ovary: a clinicopathologic analysis of 120 cases with emphasis on their variable pathologic manifestations. Am J Surg Pathol 2006; 30: 277-99.

5. Fazzari C, Fedele F, Pizzi G, Crisafulli C, Parisi A, Caruso RA. Krukenberg tumour of the ovary: a case report with light microscopy, immunohistochemistry and electron microscopy study. Anticancer Res 2008; 28: 1417-20.

6. Macdonald JS, Smalley SR, Benedetti J, et al. Chemoradiotherapy after surgery compared with surgery alone for adenocarcinoma of the stomach or gastroesophageal junction. N Engl J Med 2001; 345: 725-30

7. Van Cutsem E, Moiseyenko VM, Tjulandin S, et al. Phase III study of docetaxel and cisplatin plus fluorouracil compared with cisplatin and fluorouracil as first-line therapy for advanced gastric cancer: a report of the V325 Study Group. J Clin Oncol 2006; 24: 4991-7.

8. Kong X, Wang JL, Chen HM, Fang JY. Comparison of the clinicopathological characteristics of young and elderly patients with gastric carcinoma: a meta analysis. J Surg Oncol 2012; 106: 346-52.

9. Maehara Y, Sakaguchi Y, Moriguchi S, Orita H, Korenaga D, Kohnoe S, Sugimachi K. Signet ring cell carcinoma of the stomach. Cancer 1992; 69: 1645-50.

10. Kim DY, Park YK, Joo JK, Ryu SY, Kim YJ, Kim SK, Lee JH. Clinicopathological characteristics of signet ring cell carcinoma of the stomach. ANZ J Surg 2004; 74: 1060-4.

11. Piessen G, Messager M, Leteurtre E, Jean-Pierre T, Mariette C. Signet ring cell histology is an independent predictor of poor prognosis in gastric adenocarcinoma regardless of tumoral clinical presentation. Ann Surg 2009; 250: 878-87.

12. Otsuji E, Yamaguchi T, Sawai K, Takahashi T. Characterization of signet ring cell carcinoma of the stomach. J Surg Oncol 1998; 67: 216-20.

13. Zhang M, Zhu G, Zhang H, Gao H, Xue Y. Clinicopathologic features of gastric carcinoma with signet ring cell histology. J Gastrointest Surg 2010; 14: 601-16.

14. Li C, Kim S, Lai JF, Hyung WJ, Choi WH, Choi SH, Noh SH. Advanced gastric carcinoma with signet ring cell histology. Oncology 2007; 72: 64-8.

15. Novak C, Gray LA. Krukenberg tumor of the ovary: clinical and pathological study of four cases. Surg Gynecol Obstet 1938; 66: 157-65.

16. Prat J. Ovarian carcinomas, including secondary tumors: diagnostically challenging areas. Mod Pathol 2005; 18: 99-111.

17. Lerwill MF, Young RH. Ovarian metastases of intestinal-type gastric carcinoma: a clinicopathologic study of 4 cases with contrasting features to those of the Krukenberg tumor. Am J Surg Pathol 2006; 30: 1382-8.

18. Takenoue T, Yamada Y, Miyagawa S, Akiyama Y, Nagawa H. Krukenberg tumor from gastric mucosal carcinoma without lymphatic or venous invasion: report of a case. Hepatogastroenterology 2001; 48: 1211-4.

19. Kakushima N, Kamoshida T, Hirai S, et al. Early gastric cancer with Krukenberg tumor and review of cases of intramucosal gastric cancers with Krukenberg tumor. J Gastroenterol 2003; 38: 1176-80.

20. Baba Y, Ishikawa S, Ikeda K, Honda S, Miyanari N, lyama K, Baba H. Patient with 43 synchronous early gastric carcinomas with a Krukenberg tumor and pericardial metastasis. Gastric Cancer 2007; 10: 135-9.

21. Lee SR, Kim HO, Son BH, Shin JH, Yoo CH. Prognostic significance of the metastatic lymph node ratio in patients with gastric cancer. World J Surg 2012; 36: 1096-101.

22. Shiraishi N, Sato K, Yasuda K, Inomata M, Kitano S. Multivariate prognostic study on large gastric cancer. J Surg Oncol 2007; 96: 14-8.

23. Quiros RM, Desai DC. Multidisciplinary approach for the treatment of gastric cancer. Minerva Gastroenterol Dietol 2011; 57: 53-68.

24. Song S, Chie EK, Kim K, et al. Postoperative chemoradiotherapy in high risk locally advanced gastric cancer. Radiat Oncol J 2012; 30: 213-7.

25. Smalley SR, Benedetti JK, Haller DG, et al. Updated analysis of SWOG-directed intergroup study 0116: a phase III trial of adjuvant radiochemotherapy versus observation after curative gastric cancer resection. J Clin Oncol 2012; 30: 2327-33.

26. Nowara E, Boratyn-Nowicka A, Polakiewicz-Gilowska A, Drosik A Kustra M, Huszno J. Chemotherapy for gastric cancer patientstime for personalization in medicine? Wspolczesna Onkol 2012; 16: 86-9.

27. Pasini F, Fraccon AP, DE Manzoni G. The role of chemotherapy in metastatic gastric cancer. Anticancer Res 2011; 31: 3543-54.

28. Arkenau HT, Saggese M, Lemech C. Advanced gastric cancer: is there enough evidence to call second-line therapy standard? World J Gastroenterol 2012; 18: 6376-8. 
29. Ueda K, Iwahashi M, Nakamori M, Nakamura M, Naka T, Ishida K, Ojima T, Yamaue H. Analysis of the prognostic factors and evaluation of surgical treatment for synchronous liver metastases from gastric cancer. Langenbecks Arch Surg 2009; 394: 647-53.

30. Takemura N, Saiura A, Koga R, et al. Long-term outcomes after surgical resection for gastric cancer liver metastasis: an analysis of 64 macroscopically complete resections. Langenbecks Arch Surg 2012; 397: 951-7.

31. Lu LC, Shao YY, Hsu CH, Hsu C, Cheng WF, Lin YL, Cheng AL, Yeh KH. Metastasectomy of Krukenberg tumors may be associated with survival benefits in patients with metastatic gastric cancer. Anticancer Res 2012; 32: 3397-401.

32. Jun SY, Park JK. Metachronous ovarian metastases following resec tion of the primary gastric cancer. J Gastric Cancer 2011; 11: 31-7.

\section{Address for correspondence}

Assist. Prof. Dr. Ummugul Uyeturk

Department of Medical Oncology

Abant Izzet Baysal University Faculty of Medicine

14280 Bolu, Turkey

e-mail: ummuguluyeturk@yahoo.com.tr

Submitted: 24.03 .2013

Accepted: 8.05 .2013 